\title{
Research Paper Time series analysis of chilli (dry) prices in selected markets of India
}

See end of the paper for authors' affiliations

Correspondence to :

S. B. RAMYA LAKSHMI

Department of Agricultural Economics, S.V. Agricultural College, TIRUPATI (A.P) INDIA

Email : ramyalakshmi.sb@ gmail.com

\section{Paper History :}

Received : 03.01.2017;

Revised : 13.07.2017;

Accepted : 26.07.2017
Abstract : Chilli is one of the most important spice crops in India. The present study was undertaken to forecasts the prices of chilli (dry) in different markets of India using various techniques. ARIMA model $(1,1,1)$ was identified as the best model to forecast prices in Byadagi market. According to the forecasts the price of chilli per quintal would be ranging from Rs. 6,394 to Rs. 6,546 for the months from April to July 2013. The model $(1,0,1)$ was selected for forecasting prices of chilli in Nagpur market. The forecasts indicated that the prices of chilli per quintal would be ranging from Rs. 5,364 to Rs. 5,200 for the months from April to July 2013. The models $(1,1,0)(1,1,1)$ were selected for forecasting prices of chilli in Virudhunagar market. The forecasts revealed that the prices of chilli per quintal would be in the range of Rs. 5,473 to Rs. 5,456 for the months commencing from April to July 2013.

KEY WORDS : ARIMA, Forecasts

How To Cite This PAper : Lakshmi, S.B. Ramya and Devi, I. Bhavani (2017). Time series analysis of chilli (dry) prices in selected markets of India. Internat. Res. J. Agric. Eco. \& Stat., 8 (2) : 271-276, DOI : 10.15740/HAS/ IRJAES/8.2/271-276. 